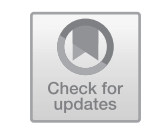

\title{
Somatology: Notes on a Residual Science in Kant and the Seventeenth and Eighteenth Centuries
}

\author{
Francesco Valerio Tommasi
}

The considerations I am going to present in this exposition represent the first step of a broader research I would like to start on the topic of the history of a peculiar discipline called 'somatology'. Therefore, what I am outlining today is not yet a refined and precise description, but rather a sort of roughly ordered presentation of some material I have been able to dig up so far. This is one necessary premise.

Somatology is an 'invention' of early modern Protestant Scholasticism and is mentioned by Immanuel Kant. Consistently with the way in which this discipline was considered in the Seventeenth and Eighteenth Centuries, somatology is for Kant the discipline that has to do with material physical objects and therefore with 'bodies' conceived in a broader sense. But somatology is also for him the counterpart of pneumatology or psychology, as sciences dealing with the spirits of the soul. Therefore, somatology is for Kant also a part of anthropology and specifically of the part regarding human bodies: This feature is also typical of

F. V. Tommasi $(\bowtie)$

Sapienza Università di Roma, Rome, Italy

(C) The Author(s) 2018

G. Lorini and R. B. Louden (eds.),

Knowledge, Morals and Practice in Kant's Anthropology, https://doi.org/10.1007/978-3-319-98726-2_9 
somatology in general at that time. So somatology is for Kant a science concerning physical matter in general and a science concerning animal and specifically human bodies in particular. This duplicity is constitutive of somatology since its very beginning and constitutes its central problem. Kant is therefore paradigmatic of a central problem affecting this discipline. This problem seals the fate of somatology, its short life in the tree of sciences and of its final failure. Kant himself refers very seldom to somatology, providing therefore indirect confirmation for a general thesis that guides my reconstruction of the history of somatology, namely that it is a sort of 'residual' science.

As a discipline concerning a rational, pure, therefore philosophical consideration of the human body, somatology had a relatively short and marginal life, and from the beginning, it was 'crushed' between physics as a general science of the physical and material objects and medicine as an empirical and objective-but not philosophical-consideration of the specificity of the human body, with all its related sciences (namely biology, physiology, and anatomy). From its very beginning, somatology was considered a counterpart to psychology, and together, they constituted anthropology. All these terms - as we know and shall briefly underline here-are an invention of the early modern times and its reshaping of the tree of sciences.

\section{Kant And Somatology}

Kant explicitly mentions somatology at least once, in a reflection of the Handschriflicher Nachlass. It is the reflection number 4168, written on Kant's exemplar of Baumgarten's Metaphysics, and it is ascribed by Adickes to the beginning of the Seventies. Kant says:

Die metaphysic ist eine Wissensehaft hat entweder bloße obiecten der reinen Vernunft zum Gegenstande oder auch Gegenstände der Sinne, wovon sie die Gründe und ihre Natur nicht durch die Sinne, sondern durch reine Vernunft kennen lernt; ienes ist der allgemeine, dieses der besondere Theil (Metaphysica applicata) und besteht aus der pneumatologia und somatologia pura; vor beyden muß die physiologia des innern oder äußern Sinnes vorgehen, aber nicht vor der metaphysica universali, nemlich der ontologie und theologia generali, deren die erste das oberste principium aller Erkenntnisse durch reine Vernunft, die zweyte das oberste durch reine Vernunft zu erkennende principium aller Dinge betrachtet. 
In der ontologia wird alles betrachtet disiunctive, in der theologia Naturali und cosmologia alles collective. (HN, AA 17: 441-442; 2005: 117)

Somatology is here situated alongside pneumatology-the science of the spirit, pneuma-another title name invented in the context of the German Scholasticism in the early modern times. According to Kant, both somatology and pneumatology refer to the applied part of metaphysics, as opposed to general metaphysics, where ontology and theology belong. Besides the unusual fact that here Kant also ascribes theology to general metaphysics, and besides the odd role of cosmology, that is mentioned only at the end and seems somehow external to the system, this presentation is also very peculiar as to what pertains to pneumatology and somatology.

They both refer to sensible objects (Gegenstände der Sinne); this is very easily comprehensible for somatology; but what about pneumatology as a science of the spirit? Probably Kant already considers psychology as a completely empirical discipline-or at least as one that has an important empirical part: something very close to physiology, which in fact is explicitly mentioned as a necessary premise to it: Physiology of the 'inner sense' must come before pneumatology just as physiology of the 'outer sense' must come before somatology. Physiology is considered a sort of 'transcendental' premise to applied metaphysics. And physiology of the outer sense, as a physiology relating to space, can probably be understood as something very close to a physiology of the body.

This sort of bodily physiology makes possible a somatology which, in its turn, is defined by Kant as 'pure': It is in fact the rational knowledge of the sensible objects given in the outer space (Gegenstände der Sinne, wovon sie die Gründe und ihre Natur nicht durch die Sinne, sondern durch reine Vernunft kennen lernt). For that reason, this somatologia pura is not only concerned with the human body, but more broadly with all empirical objects. Neither is a mere physics, but rather a rational physics or metaphysics of nature. Pure somatology is a priori and rational, a philosophical science. It is also different from cosmology, which is something closer to a general science of the world as a whole.

This Kantian reflection stays very close to a passage of the Architectonic of the Critique of Pure Reason in which Kant describes again the field of metaphysics. I have to present here a long quotation: 
Die im engeren Verstande so genannte Metaphysik besteht aus der Transscendentalphilosophie und der Physiologie der reinen Vernunft. [...] die zweite betrachtet Natur, d. i. den Inbegriff gegebener Gegenstände (sie mögen nun den Sinnen, oder, wenn man will, einer andern Art von Anschauung gegeben sein), und ist also Physiologie (obgleich nur rationalis). Nun ist aber der Gebrauch der Vernunft in dieser rationalen Naturbetrachtung entweder physisch oder hyperphysisch, oder besser, entweder immanent oder transscendent. [...] Die immanente Physiologie betrachtet dagegen Natur als den Inbegriff aller Gegenstände der Sinne, mithin so wie sie uns gegeben ist, aber nur nach Bedingungen a priori, unter denen sie uns überhaupt gegeben werden kann. Es sind aber nur zweierlei Gegenstände derselben: 1. Die der äußeren Sinne, mithin der Inbegriff derselben, die körperliche Natur. 2. Der Gegenstand des inneren Sinnes, die Seele, und nach den Grundbegriffen derselben überhaupt die denkende Natur. Die Metaphysik der körperlichen Natur heißt Physik, aber, weil sie nur die Principien ihrer Erkenntniß a priori enthalten soll, rationale Physik. Die Metaphysik der denkenden Natur heißt Psychologie, und aus der eben angeführten Ursache ist hier nur die rationale Erkenntniß derselben zu verstehen. Demnach besteht das ganze System der Metaphysik aus vier Haupttheilen: 1. Der Ontologie. 2. Der rationalen Physiologie. 3. Der rationalen Kosmologie. 4. Der rationalen Theologie. Der zweite Theil, nämlich die Naturlehre der reinen Vernunft, enthält zwei Abtheilungen, die physica rationalis ${ }^{*}$ ) und psychologia rationalis. ( $\mathrm{KrV}: \mathrm{A}$ 845-6/B 873-4; 1998: 698-699)

In this passage, the place of pure somatology is taken by rational physics, a term that Kant seems to prefer and indeed uses often in his works. Rational physics is situated again next to rational psychology, and both constitute rational physiology. Therefore, in this passage, physiology is no longer a premise, but the general concept of a science of nature, divided into physical nature and thinking (spiritual) nature, according to the knowledge based on the inner or the external sense. Physiology is no longer an anthropological, 'subjective' and 'transcendental', premise, but directly the science that concerns the objects of nature, made up of two branches.

Two matters of fact are important to us: (1) Somatology corresponds in Kant to rational physics; therefore, it is not a specific science of the human body, but rather a philosophical science of nature. (2) An eventual science regarding the (or grounded in-but the oscillation is significant, as I will say) human body, that Kant somehow admitted in the 
above-quoted reflection, when he spoke of a physiology of the external sense as a premise to rational physics or somatology, cannot find an easy place and tends to disappear. There seems to be no room for a specific science devoted to the body; from an empirical point of view, the human body is considered by medical sciences; and from a pure, rational of philosophical point of view-for what concerns its 'metaphysical' role or its a priori nature-it is not specifically distinguished from all other physical and empirical objects.

\section{The Invention of the Term 'Somatology'}

The same problem can be found at the very beginning of the history of somatology, and it is constitutive of its nature. As we said, the name is an invention by authors of the so-called German Scholasticism, in the early modern period, just as is the case with some other disciplines, like ontology, psychology, or anthropology-names destined to a better fortune than ones like gnostology or noology, for example, which soon disappeared as disciplines, but which had been conceived as sciences of knowledge. As Wilhelm Risse describes it, all these sciences are a sort of product of the ramist tendency to create a new organization of sciences, different from the Aristotelian model, and specifically according to the ramist idea of 'technology', which was understood as a method to assign to each subject matter a special place in the general map of knowledge. Starting from the Protestant reorganization of academies at the end of the Sixteenth Century onwards, this German milieu gave rise to many new disciplines and invented many names.

We know, for example, that the name 'ontology' was widespread thanks to its appearance in the article 'abstraction' in the Lexicon of Goclenius, published in 1613, even if it can already be found in the work Ogdoas scholastica by Lorhard in 1609. Again, the first person to have used the term anthropology_as far as we know-seems to have been Magnus Hundt (1449-1519) in his work Anthropologium de hominis dignitate, natura et proprietatibus; de elementis, partibus et membris humani corporis [...] De spiritu humano [...] De anima humana published in 1501, but this peculiar name for a science started to be widespread only at the end of the Sixteenth Century thanks to the work of Otto Casmann.

Something similar can be said of psychology: We have witnesses of a first occurrence of the term in the title of a work by Marko Marulič, 
Psichiologia de ratione animae humanae, published around 1520. This work seems to have stayed within the sphere of influence of Byzantine tradition and probably had no later influence, when a new and independent tradition was probably started by Johannes Thomas Freigius, under the influence of Melanchthon, in his Catalogus locum communium of 1575: Psychology is described here as a natural science, belonging to physics and not to metaphysics. Then again Rudolph Goclenius wrote a Psychologia, hoc est de hominis perfectione, published in 1590, and Rudolph Snellius, in its Snellio-Ramaeum philosophiae syntagma (1596), divided philosophy into 8 branches and described psychology as a part of physics. The science of the natural and empirical entities is divided by him as follows: physics of mple bodies (astrology and physiology) and physics of composite bodies (meteorology and psychology): “agit enim psychologia de corporibus animatis" (p. 4).

For what concerns somatology, its first occurrence must likely be attributed to the work of the already quoted Otto Casmann (15621607), a pupil of Goclenius in Marburg. As we anticipated, analyzing somatology in Kant, already for Casmann somatology is a synonym of general physics and therefore not a specific science of the human body. The latter is rather called by Casmann 'somatotomia'. Casmann writes: "Anthropologia est doctrina humanae naturae. Humana natura est geminae naturae mundanae, spiritualis et corpareae, in unum hyphistamenon unitae particeps essential" (Casmann 1594: 1). The mundane nature is the mere physical, and is treated by somatology, as far as also man is part of empirical nature broadly considered. The spiritual part is subject of psychology and pneumatology. And the "natura corporea" is treated by somatotomy, as I already said.

There are three works of Casmann corresponding to these three parts: a Somatologia physica generalis, published in 1598, a Psychologia anthropologica, sive animae humanae doctrina (Hanau 1594), and an Anthropologiae pars II. h. e. de fabrica humani corporis methodice descripta (Hanau 1596). At the very beginning of this last book (p. 1), we read: "est autem Somatotomia hominis pars altera anthropologiae, humani corporis naturam membratum explicans". The so-called somatotomy concerns the bodily part of anthropology. This volume is practically a book on anatomy, it describes the parts of the human body, and it is-beginning with the title-in many parts based on the works of Vesalius and Fernel. 
In 1542, Jean Fernel wrote a De naturali parti medicinae, which is considered the first modern study on physiology, a term introduced by him in the second edition of this work: The subject of this again newly invented science (or at least a rediscovered term, since it is attested in ancient Greek authors) is the "knowledge of the nature of the sane man, of all his strengths and functions". Fernel is the first one who abandoned the paradigm based on humors and introduced an explanation based on solid organs. Anatomy - he said — is as relevant to medicine as geography is to history.

Indeed, in 1543, Vesalius published a work with the same title that later was to be chosen by Casmann, that is: De fabrica humani corporis. This volume is considered a milestone in the history of medicine, because for the first time, empirical observations were considered more authoritative than Galen. During the Renaissance, there was a slow and not easyprogressive acceptance of anatomy by the Church: Sixtus IV and then Clemens VII formally authorized this kind of study that hitherto had been just tolerated: At the end of the Thirteenth Century, Mondino de Liuzzi wrote a treatise on Anothomia and this book is usually considered as a forerunner of the modern development of this science. Then, during the Renaissance, Galen was edited first in Latin (1490) and then in the original Greek version (1523), but a decisive role was also played by the arts: Leonardo, Michelangelo, and Dürer, for example, provided studies on the human body and worked together with doctors-or were themselves devoted to medical studies, like Leonardo.

The famous work of William Harvey on blood circulation published in 1628 is entitled: Exercitatio anatomica de motu cordis et sanguinis, and Jacob de Back, who wrote a commentary on it in 1653, which is entitled Discourse of the heart, divided anthropology into psychologia, somatologia, and hematologia. This new scientific approach will lead to the work of Giovanbattista Morgagni, written in 1761, De sedibus et causis morborum per anatomen indagatis, usually regarded as the definitive modern treatise on anatomy.

Going back to Casmann, it is important to acknowledge that, generally speaking, his work must be inscribed in the above-mentioned rediscussion of the Aristotelian framework, even though it still depends on a hylomorphic model. Soul and body are considered as complementary. Another witness of this symmetrical idea can be found in this other work by Casmann: Homo novus sive spiritualis, in quo de eius generatione, parentibus, conceptione, formatione, intellectu, prudentia, conscientia, sancta 
voluntate \& actione, nutrimento \& augmento, totaque vita sancte instituenda. Casmann tends to a kind of dualistic approach as a result of the debate between Scaliger and Goclenius, one of the numerous debates on the possible materialistic interpretation of Aristotle's De anima. The human body in itself is not capable of being considered as a man. It is just a physical machine. But the spiritual, even if fully detached and independent from any material influence, can only be conceived in analogy to the body. So here we face something like a pre-Cartesian model.

There are further traces of the diffusion of the term 'somatology' in the milieu around Rudolph Goclenius. Thomas Wetzel discussed with him a dispute on this topic in 1609 in Marburg. This work is attested in the Allgemeine Deutsche Biographie (ADB 1897: 259-260), but I haven't yet found any existing copies of it. Moreover, in neither one of both famous Goclenius' Lexica was I able to trace any explicit clue either of somatology, or of somatotomy. But neither anthropology nor psychology is to be found in those pages. On the contrary, we have both 'corpus' and 'anima' in the Latin Lexicon and 'soma' and 'psyche' in the Greek one. What is interesting sub voce 'corpus' in the Latin Lexicon philosophicum (1613) is the fact that we find well expressed the general problem of a philosophical treatment of the human body. Goclenius writes:

Corpus accipitur dupliciter: uno modo ut est in categoria substantiae; altero ut est ex genere quantitatum. Corpus, quod est substantia, est subiectum triplicis dimensionis, longitudinis, latitudinis et profunditatis. Estque nihil aliud, quam vel substantia corporea, ac tunc genus est, vel materialis pars substantiae corporatae, ut cum opponitur animae, vel significat carnem oppositam sanguini. Corpus, quod est quantitas, est tres dimensiones. (Goclenius 1613: 481)

This passage is not so easily interpreted, at least for me. As far as I can understand, a body can be a substance, and in that case, it means a general, material, and physical body, defined only through the fact of being the subject of three dimensions, that means: being extended in space. This is the reason why the term 'body' can also simply express a quantity, a predicate, not being a substance: Goclenius in fact repeats that in this second case "corpus, quod est quantitas, est tres dimensiones". So, a body is either a material and extended substance, or is a simple extension as a category of quantity. But what gives the possibility of becoming a substance to the quantity or to the extension? It can't be anything else 
than a form. So the body, as a substance, must in any case be informed by something else and there cannot be something like a 'pure' body as a 'pure extension'. A bodily substance is therefore always extension or materiality plus something else. In fact, when Goclenius describes the possible bodily substances he says: (1) Body is a genus: That means a mere concept. (2) Body is the material counterpart of the soul, which is its form. But then the substance is the man, not the body, which cannot remain independently. (3) Or body is flesh, as opposed to blood.

We are confronted here-in my opinion-with the general problem of the possibility of pure somatology: It is impossible to conceive something like a 'pure body', if body simply means three-dimensional extension, or materiality, or a quantity. The problem is particularly urgent when it comes to human nature: The tradition based on the general assumption of the 'anima forma corporis' is not able to assume a proper form of the body in itself. It is no chance that among scholastic authors many discussions arose over the problem of the so-called forma cadaverica. When the soul-conceived as the form of the body-leaves the body in the moment of death, the corpse needs some other kind of form. And it is again no chance that another meaning of body is found by Goclenius in the flesh-'caro'-the chair of the French phenomenological tradition trying to translate the term Leib as a living, proper, human body. Indeed, German is one of the few languages owning a special term for the human body as specifically distinguished from all other Körper. So, in German Lexica of the Eighteenth Century, like the one of Walch, or the one of Zedler, we find a specific article devoted to the human body-Leibeven if no mention of somatology.

The title term 'somatology' is then widespread during the Seventeenth and Eighteenth Centuries and can be found in various authors, even if its success is not that great. A relatively good diffusion of the use of the term somatology can be noted especially in England as the example of the above-quoted commentary on the work of Harvey already testified. The rather empirical tradition of this intellectual and philosophical ambient can maybe explain this circumstance.

A link between the German and the English world as regards the use of the term somatology can be found in the work of Samuel Strimesius, born in Königsberg in 1648. A physicist and theologian, he studied in Oxford and Cambridge, probably due to the influence of his mother, who was an English woman. Strimesius was himself father of Johann Samuel Strimesius, later professor of rhetoric in Königsberg in the time 
when Kant was a student there. Samuel Strimesius-namely the fatherwas near to the Cambridge Platonists and is often quoted in the histories of philosophy for his sharp criticism of Hobbes' empiricism: He qualified the author of the Leviathan and of the De corpore as a "diabolus incarnatus": Against Hobbes, he wrote a Praxiologia Apodictica, Seu Philosophia Moralis Demonstrativa: Pythanologiae Hobbesianae Opposita (published in 1677). And precisely what concerns the description of the body, there have already been speculations on a possible dependence of Thomas Hobbes on Goclenius. ${ }^{1}$

But Samuel Strimesius was also the author of a Somatologia apodictica, seu philosophia naturalis demonstrative (published in 1679) and of a Somatologia seu physica, media, Aristotelem inter \& cartesium, incedens (published in 1697) (Until now, I have had the opportunity only to look at the first book, but I suspect that the content of both is very similar, or at least that the second one is a sort of updated version of the first one). It is also interesting to note that Strimesius' Somatologia apodictica is quoted by Leibniz, even if in a marginal note. ${ }^{2}$

\section{The Philosophical Science of the Body}

Through this link to Leibniz, we land somewhere close to the milieu of the Berlin Academy. It would indeed be very likely to find some mentions of somatology in this milieu, which took a strong interest in empirical and natural sciences. In the Memoires of the Academy, it is possible to find many essays and studies dedicated to physical and medical arguments, and it is significant that they have been gathered together in a number of volumes: two from 1781, then one in 1783, and another in 1786.

In these four volumes, it is possible to find many specific and detailed analyses of topics regarding the whole spectrum of natural sciences: from physics to biology and entomology, from chemistry to astronomy, from physiology to anatomy to medicine, and so on, beginning with a Geschichte der Erfindung des Phosphorus written by Leibniz. Among the authors who contributed, we can find very famous names, like Leonhard Euler, or names that are also well known in the history of philosophy

\footnotetext{
${ }^{1}$ See C. H. Leijenhorst and C. Leijenhorst (2002: 145ff).

${ }^{2}$ See G. W. Leibniz (1679-1687?-2006: 1788-1789).
} 
like the ones of Johann Georg Sulzer or Etienne Chauvin. There are also many specific studies on anatomy, like the analysis of Augustin Buddeus on the bones and on the corpses, and the many essays on chirurgy and blood by Johann Theodor Eller. Eller is also the author of a Description d'un monstre cyclope mis au monde à Berlin le 19 de Féprier de l'année 1745, a work that testifies to the interest at that time for odd and monstrous images also in the empirical and scientific field.

As far as I have been able to discover, there aren't any mentions either of somatology or of somatotomy in any of these studies. And those disciplines are not mentioned either in the history of the Academy written by Harnack. Two Preisfragen were dedicated to possibly related topics, respectively, to the following subjects: "Si l'on peut détruire les penchants qui viennent de la Nature, ou en faire naitre qu'elle n'ait pas produits et Quels sont les moyens de fortifier les penchants lorsqu'ils sont bons, ou de les affaiblir lorsqu'ils sont mauvais, suppose qu'ils soient invincibles?" (1768) and "Examen des deux facultés primitives de l'âme. Celle de connaitre et celle de sentir (1773)". But as far as I was able to findsome materials - actually very few-regarding those two Preisfragen, again there is no somatology.

In the Geschichte of Harnack, we find some space devoted to anatomy and especially to the theatrum anatomicum - another very famous and important modern invention-that was established also in the Academy. ${ }^{3}$ It is easy to understand how far the Academy was interested in scientific and empirical themes and again how less space was left to the possibility of a specific philosophical science of the human body. It is significant that in the third volume of Harnack's history, anthropology is situated at the end, as an apex, of the physical and empirical science, and at the beginning of the later so-called Geisteswissenschaften. Anthropology comes after paleontology and zoology, begins with anatomy and physiology and practical medicine, and culminates into ethnology, the forerunner of cultural anthropology. 4

As the beginning part of anthropology, somatology will appear again during the nineteenth and still into the twentieth century, when it will also be placed near physiognomics, anthropometrics, and the attempts to give moral and spiritual value to anatomical elements. In fact, the

\footnotetext{
${ }^{3}$ See A. v. Harnack (1900, Bd. 2: 226ff).

${ }^{4}$ See A. v. Harnack (1900, Bd. 3: 482ff).
} 
Anglo-Saxon milieu is the one where 'somatology' can be found more often. A quotation of the American thinker Noah Porter is a good example of the architectonic role of this science, still considered as a part of anthropology.

A more exact division of anthropology separates it into somatology and psychology. Somatology signifies the science of the body only and is subdivided into anatomy and physiology — anatomy being the science of its structure, and physiology the science of the functions of its organs. Psychology might also be divided into the lower and higher psychology. It has been distinguished by earlier and later writers as empirical and rational, the first giving the facts, the second the rationale, or the philosophical interpretation of the facts. (Porter 1887: 7)

But still Jeremy Bentham divides his 'idioscopic ontology' into somatology and pneumatology. ${ }^{5}$ The destiny of somatology seems to be strictly related to the one of anthropology, and therefore, it is no wonder that, in the Eighteenth Century, the Berlin Academy could not find a proper place for this science, as the body is either something physical, and, therefore, an object of medicine, or something that is a mere instrument of the psychological and spiritual part of the human. A very good witness of this problem is again Kant, who sharply distinguished between a physiological and a pragmatic anthropology.

So, let me conclude by coming back to Kant: There is another-albeit indirect-mention of somatology in his work, namely in a letter written to him by Christian Gottfried Schütz of Jena on the 8th of November, 1785. In this text, Schütz tells Kant about the difficulties of introducing Kantian philosophy in that academic milieu, owing especially to the opposition of Justus Christian Hennings, who was preferred to Kant by that university as an ordinary professor, to teach logics and metaphysics after Darjes retired. ${ }^{6}$ Hennings also stays somehow indirectly close to the Berlin Academy, as he was member of the Königlich preußische Gesellschaft der Wissenschaften in Frankfurt/Oder, Assessor of the Königlich dänisch Norwegische Akademie in Drontheim, and also member of the Herzogliche Teutsche Gesellschaft der höheren Wissenschaften in Jena and honorary member of the Mineralogische Gesellschaft in Jena.

\footnotetext{
${ }^{5}$ See Bentham (1817: 177-179).

${ }^{6}$ See Br, AA 10: 422 .
} 
Talking about Hennings, Schütz mentions the 'monadology, somatology' and indirectly refers to a, probably at that time well known, metaphysics compendium (published in Jena in 1768), written by Hennings, that has the following 'leibnizian-scholastic' subdivision of philosophy: Philosophia prima, Ontologia, Monadologia, Somatologia and Mechanologia (placed together), Psychologia, and finally Theologia naturalis. Somatology is here again defined as the general science of 'composite beings' that are finite and contingent and opposed to the monads, simple beings. The first characteristic of that composite being is to be material and extended. Once again, no space for a pure philosophical doctrine of the human body.

No such treatment and no somatology are to be found either in Christian Wolff. But the disciple of his work, Heinrich Adam Meissner, presents a treatment of the human body that seems to have at least the potential of introducing the philosophical idea of the human body as constitutive and transcendentally necessary to human knowledge: "Unser Leib ist derjenige Cörper, nach welchem sich unsere Gedancken von den übrigen richten, und er uns allzeit gegenwärtig bleibet, wenn alle übrige sich ändern" (Meissner 1737: 346). There is no spirit and no thinking without the body, and every kind of thinking and spirit is unavoidably mediated and oriented by and through the body. This awareness, recently brought up by the stream of the so-called embodied mind theory, could finally reopen the ancient chapter of a pure somatology, which has remained until now-despite some glimpses-underground and residual.

\section{BIBLIOGRAPHY}

Allgemeine Deutsche Biographie. 1897. Wetzel, Thomas, 42, 259-260.

Bentham, Jeremy. 1817. Essay on Nomenclature and Classification. In Chresthomathia, pt. II, London: Payne and Foss.

Goclenius, Rudolph. 1613. Lexicon Philosophicum. Frankfurt: Becker.

Harnack, Adolf von (ed.). 1900. Geschichte der Königlich Preussischen Akademie der Wissenschaften zu Berlin; Bd. 1/1-2: Darstellung. Bd 2: Urkunden und Actenstücke zur Geschichte der Königlich Preussischen Akademie der Wissenschaften; Bd. 3: Gesamtregister über die in den Schriften der Akademie erschienenen wissenschaftlichen Abhandlugen und Festereden. Berlin: Königlich Preußischen Akademie der Wissenschaften. 
Leibniz, Gottfried Wilhelm von. 2006 [1679-87?]. Philosophische Schriften, Bd. IV. Berlin: Akademie Verlag.

Leijenhorst, Cornelis Hendrik, and Cees Leijenhorst. 2002. The Mechanisation of Aristotle. The Late Aristotelian Setting of Thomas Hobbes' Natural Philosophy. Leiden, Boston, and Köln: Brill.

Meissner, Heinrich Adam. 1737. Philosophisches Lexicon Aus Chr. Wolffs sämtl. Dtsch. Schr. Bayreuth and Hof: Verlag Johann Gottlieb Bierling.

Porter, Noah. $1869^{1}, 1887^{4}$. The Human Intellect: With an Introduction Upon Psychology and the Soul. New York: Charles Scribner's Sons. 